\title{
Premalignant Neoplasm
}

National Cancer Institute

\section{Source}

National Cancer Institute. Premalignant Neoplasm. NCI Thesaurus. Code C36032.

A neoplasm that is composed of dysplastic cells and there is no morphologic evidence of infiltration of the surrounding tissues. 